\title{
BUDAYA BELAJAR MANDIRI DAN PENDIDIKAN AGAMA ISLAM \\ di TINGKAT SEKOLAH MENENGAH PERTAMA
}

\section{Nurhayati}

\begin{abstract}
The present paper investigates whether autonomous learning can improve their Islamic knowledge. The favorable characteristics of autonomous learning are used as the basis for (1) arguing against the assumption that Indonesian learners are dependent on their teachers and (2) arguing for its adoptions in improving student. The paper also discusses how to incorporate autonomous learning in competency based curriculum.
\end{abstract}

Key Words: Autonous learning, competency based curriculum

\section{PENDAHULUAN}

Isu yang berkembang dalam pengajaran materi pendidikan agama Islam adalah bahwa para siswa sekolah menengah pertama khususnya negeri (selanjutnya disingkat SMPN) umumnya mempunyai kemampuan yang terbatas dalam membaca tulisan berbahasa Arab. Keterbatasan kemampuan berbahasa Arab para siswa SMPN itu dianggap sebagai akibat dari kurang berhasilnya pengajaran Agama di tingkat sekolah dasar. Konteks peristiwa yang memperlihatkan ketidakberhasilan pengajaran baca tulis berbahasa Arab pada sekolah dasar negeri diakibatkan penekanan pengajaran yang diberikan bukan pada penguasaan membaca huruf Al-quran yang berbahasa Arab tetapi pada penguasaan konsep yang menyangkut pendidikan pengetahuan agama Islam. ${ }^{1}$

Kementerian Agama melalui Undang-Undang Nomor 17 tahun 2007, menjelaskan bahwa kedudukan pembangunan fungsi pendidikan dan Agama Islam tak terpisahkan dalam kerangka pembangunan nasional di bawah payung pembangunan sumber daya manusia dan

\footnotetext{
${ }^{1}$ Abdullah. Pendidikan Agama Islam Penting Untuk Bangsa. (Jakarta: 2002), h. 23
} 
kesejahteraan rakyat. Pendidikan Agama Islam diselenggarakan untuk; (a) memenuhi tugas negara, pemerintah, masyarakat, keluarga, orang tua, wali dan lembaga sosial dalam melindungi hak anak untuk memeluk ajaran agamanya meliputi pembinaan, pembangunan dan pengamalan ajaran agama, serta (b) memberikan layanan pendidikan untuk meningkatkan keimanan dan ketakwaan serta akhlak mulia dalam rangka mencerdaskan kehidupan bangsa. ${ }^{2}$ Pemerintah Indonesia melalui Kementerian Agama itu telah berupaya memperbaiki kualitas pembelajaran pada sekolah menengah pertama dengan mengadakan perubahan pada kurikulum dan metode pengajaran dari mulai pendekatan konvesional hingga diterapkannya pendekatan komunikatif, kontekstual dan saat ini kurikulum berbasis kompetensi. Untuk tingkat sekolah menengah pertama, selain mengadakan pergantian kurikulum pemerintah juga perlu memberi perhatian terhadap perbaikan proses pengajaran materi pendidikan agama Islam. Salah satu cara yang dilakukan dalam rangka peningkatan layanan dalam bahasa Arab pada sekolah menengah itu adalah Inpres No 5 tahun 2006 tentang Gerakan Nasional Percepatan Penuntasan Wajib Belajar Pendidikan Dasar Sembilan Tahun dan pemberantasn Buta Aksara. Pemberantasan buta aksara dapat dilakukan secara formal di sekolah dan secara informal lewat Taman Pengajian Alquran. Sekolah dan Taman pengajian Al-quran yang banyak diselenggarakan di berbagai masjid yang ada di tengah masyarakat telah berhasil memperkenalkan sarana belajar mandiri. Yang menjadi pertanyaan adalah Apakah sistem belajar mandiri dapat diterapkan di seluruh masjid yang ada di Indonesia? Apakah pelajar Indonesia telah mengetahui strataegi belajar yang efektif yang dapat digunakan dalam sarana belajar mandiri? Pertanyaan-pertanyaan ini menjadi penting

\footnotetext{
${ }^{2}$ Kementerian Agama. Pendidikan Agama Islam. (Pedoman Pendidikan Agama di Sekolah). Jakarta: Kementerian Pedndidikan Agama (Jakarta: 1999). h. 36.
} 
karena pelajar di Indonesia telah terbiasa belajar di dalam kelas di mana seorang guru menyampaikan isi pelajaran dan bahkan seorang guru sering dianggap sebagai satu-satunya sumber pelajaran, dengan kata lain, ketergantungan pelajar terhadap guru masih relatif tinggi.

\section{SARANA BELAJAR MANDIRI}

Sarana belajar mandiri atau yang lebih popular dengan sebutan Self-Access Centre (selanjutnya disingkat SAC) telah berhasi memasuki sistem pendidikan secara umum dan sistem pendidikan agama Islam khususnya, baik pendidikan dasar, menengah, maupun pendidikan tinggi. SAC didirikan untuk memungkinkan pelajar dapat belajar mandiri baik secara individu maupun berkelompok. Di dalam SAC pelajar dapat memilih sendiri materi pelajaran yang ingin di dalami, materi yang dapat menunjang pemahaman terhadap materi pelajaran pada saat tatap muka, dan materi yang tidak secara langsung memenuhi kebutuhan individu pelajar pada saat tatap muka.

SAC dapat diterima dalam pendidikan Islam secara umum atas dasar bahwa pelajar adalah inidividu yang memiliki kebutuhan, minat, dan tipe yang berbeda-beda. Dasar ini telah dibuat sebagai acuan dalam pengembangan serta merancang meteri pelajaran yang digunakan dalam SAC. Materi pelajaran yang dikembangkan sedemikian rupa sehingga dapat memenuhi kebutuhan pengguna yang berbeda baik dari segi latar belakang pendidikan, minat, kemampuan, cara belajar, dll. Lebih penting lagi bahwa materi pelajaran yang dikembangkan, baik latihan mapun aktifitas lainnya, disusun dan dirancang sedemikian rupa sehingga dapat digunakan secara individu, dan si pengguna dapat secara langsung mengukur tingkat keberhasilannya. Pengukuran dimaksud dapat dilakukan dengan membandingkan secara langsung hasil pekerjaan dengan kunci jawaban yang tersedia pada masing-masing 
latihan atau kegiatan. Agar materi pelajaran dalam sarana belajar mandiri dapat berfungsi dengan efektif, Sheerin memberikan beberapa saran dalam pengembangan dan rancangan materi untuk digunakan dalam SAC. Saran ini meliputi: 1) tujuan yang jelas. Tujuan yang jelas dalam materi yang dikembangkan atau didesain bermanfaat untuk memberikan gambaran yang jelas kepada pengguna, apakah meteri tersebut dapat memenuhi kebutuhannya atau tidak, 2) instruksi yang jelas. Kejelasan dalam memformulasikan instruksi membantu pengguna materi di dalam SAC untuk memilih materi yang sesuai dengan tingkat pemahamannya. Isntruksi yang jelas sebaiknya diikuti contoh untuk dikerjakan, 3) tampilan yang menarik. Materi yang dirancang untuk digunakan dalam SAC harus menarik, Tampilan materi sebaiknya mengundang perhatian pengguna yang membangkitkan rasa percaya diri dalam menggunakannya, 4) latihan/kegiatan yang bermanfaat. Latihan/kegiatan dalam SAC dirancang sedemikian rupa sehingga dapat memenuhi kebutuhan pengguna, 5) prosedur. $^{3}$ Prosedur dalam mengerjakan kegiatan yang dirancang harus mempertimbangkan bahwa sasaran dalam pengadaan SAC adalah untuk membiasakan pengguna lebih mandri, dengan demikian ada baiknya diberi kesempatan kepada pengguna untuk menerapkan cara belajar mandiri, 6) umpan balik. Pada saat belajar di dalam SAC, pada dasarnya guru tidak selalu berada di SAC. Oleh sebab itu, umpan balik sebagiknya terdapat dalam materi yang dirancang. Umpan balik dimaksud dapat berupa kunci jawaban terhadap kegaitan-kegiatan/latihanlatihan yang dirancang, sedangkan jika materi yang dirancang adalah untuk latihan membaca aya-ayat suci Al-quran maka transkrip atau teks harus tersedia, 7) materi seimbang. Dalam merencanakan materi harus dipertimbangkan keseimbangan terhadap materi, mulai dari

\footnotetext{
${ }^{3}$ Susan Sheerin. "Self-Acces"; Resource Book for Teachers. (Oxford: OUP). h. 44
} 
tingkat kemampuan hingga kebutuhan penguna. Akan tetapi, perlu digarisbawahi bahwa sebaik apapun materi yang telah direncanakan, apabila SAC diperkenalkan untuk pertama sekali perlu ada sosialisasi dan pengenalan awal terhaedap penggunaan materi untuk mendapatkan hasil ujian yang diinginkan.

\section{TINJAUAN TERHADAP HASIL BEBERAPA STUDI AWAL SARANA BELAJAR MANDIRI}

Dalam proses belajar mengajar materi pendidikan agama Islam, ada anggapan yang mengatakan bahwa "pelajar Asia" sangat tergantung kepada "guru". Ada kecenderungan menganggap guru sebagai satu-satunya sumber pengetahun. Pendapat ini mengindikasikan bahwa akan sulit bagi pelajar Asia untuk belajar tanpa kehadiran seorang guru yang berarti juga ada kesulitan dalam memperkenalkan system belajar mandiri di sekolah-sekolah di Asia. Littlewood secara tegas mengatkan bahwa berdasarkan data yang diperoleh lewat kuesioner yang dibagikan kepada pelajar di Asia dan Eropa sesungguhnya pelahar Asia tidak ingin diremeh. Pelajar Asia juga ingin mencari sendiri ilmu pengetahuan dan ingin juga mencari sendiri jawaban terhadap keingintahuan mereka. Hasil kuesioner ini juga didukung dengan hasil-hasil penelitian yang telah dilakukan di lingkungan Asia, khususnya pada institusi di mana sarana belajar mandiri telah ada. ${ }^{4}$

Indonesia sebagai salah satu negara di Asia, yang menjadi sasaran penelitian penerapan SAC hasil penelitian menunjukkan bahwa pelajar Indonesia juga menunjukkan dapat meningkatkan kemampuan baca tulis Al-quran setelah belajar baca tulis huruf Arab

${ }^{4}$ William Littlewood. “Do asian Students Really Want to Listen and Obey?” ELT Journal, Vol 54, No 1. (Oxford: OUP), h. 67. 
diintegrasikan dengan penggunaan sarana belajar mandiri secara efektif. Keberhasilan penggunaan sarana belajar mandiri secara efektif sebagai pendukung proses belajar mengajar telah nyata di Indonesia dengan semakin banyak institusi pemerintah maupun swasta mendirikan sarana belajar mandiri. Dewasa ini sarana belajar mandiri telah ditemukan di lingkungan sekolah dasar, menengah, dan perguruan tinggi di Asia., ${ }^{5}$ Dalam buku ini Miller and Garner menggambarkan secara cermat hasil studi kasus dalam pengadaan sarana belajar mandiri mulai dari tingkat sekolah dasar hingga perguruan tinggi di Malaysia dan Hongkong. Miller and Gardner ini menandaskan secara umum bahwa tujuan pengadaan sarana belajar mandiri di samping tatap muka yang berlangsung di dalam kelas, dan membuat cara belajar agama secara lebih menarik. Lebih jauh dikatakan bahwa sarana belajar mandiri akan memotivasi minat belajar, meningkatkan pelajar belajar sesuai kemampuan dan minat tanpa ada unsur paksaan.

Miller dan Gardner memberikan gambaran dalam bentuk studi kasus terhadap berdirinya SAC dari tingkat sekolah dasar hingga perguruan tinggi. ${ }^{6}$ Alasan pendirian SAC pada sekolah dasar adalah supaya pelajar dapat belajar sendiri di samping tatap muka di dalam kelas. Kegiatan belajar mandiri dianggap sebagai pelengkap terhadap tatap muka yang dilakukan di kelas. Pada tingkat ini materi difokuskan pada pengadaan permainan dan gambar-gambar yang dapat memotivasi atau menarik perhatian pelajar. SAC digunakan setiap hari dan pengajar membawa pelajar ke dalam SAC sesuai dengan jadwal pelajaran Pendidikan Agama Islam. Dengan menggunakan SAC secara regular hubungan guru dengan pelajar h. 68 .

${ }^{5}$ Lindsay Miller and David Gardner. Establishing Self-Access: From Theory Practice. (Cambdrige: 1999).

6 Ibid. 
semakin akrab dan dapat mempengaruhi cara belajar. Pada tingkatan ini kontrak terhadap materi pejaran sudah dilakukan yakni kontrak per semester. Dengan kontrak yang disepakati, guru dapat mengetahu materi yang diinginkan pelajar yang kemudian dijadikan sebagai dasar untuk penyusunan materi untuk digunakan di SAC. Pada sekolah menengah pertama SAC didirikan dengan tujuan untuk memberikan sumber belajar yang efektif dalam belajar agama Islam serta memudahkan pelajar belajr sesuai dengan kemampuan dan minat dalam suasana yang lebih bebas. Di samping itu SAC juga bertujuan untuk memperkenalkan konsep belajar secara otonomi dalam meningkatkan pengetahuan dan pengamalan dalam pendidikan agama Islam. Pada tingkat sekolah menengah pertama, SAC bertujuan untuk memenuhi berbagai macam kebutuhan yang menyangkut spritualitas Islam yang dituntut dalam bidang ilmu agama. SAC bertujuan untuk memenuhi kebutuhan masing-masing mahasiswa yang ingin belajar secara fleksibel, baik untuk lebih mendalami bidang ilmu yang ditekuni yang menggunakan teks bahasa Arab maupun untuk meningkatkan keahliannya dalam berbahasa Arab khususnya dalam membaca tulis Al-quran dan Hadist yang menjadi pedoman orang Islam. Misalnya bagi pelajar yang ingin mengetahui hukum mendirikan salat lima waktu dapat membaca di Al-qu'ran.

Beberapa penelitian lain juga telah diadakan untuk mencoba melihat kontribusi SAC dalam belajar agama Islam di Indonesia. Keberhasilan pendidikan agama Islam di Indonesia perlu digunakan pendekatan "study guides" sebagai satu pendekatan dalam belajar di dalam sarana belajar mandiri pada sekolah-sekolah menengah pertama. Sarana belajar mandiri sebagai satu komponen dalam pengajaran Agama Islam khususnya mengenai baca tulis huruf Arab. Penelitian-penelitian tentang pendidikan agama Islam di Indonesia ini menegaskan 
bahwa dengan menggunakan sarana belajar mandiri sebagai supplemen terhadap tatap muka, kemampuan membaca tulisan Al-quran yang menggunakan bahasa Arab khusus dalam bidang baca tulis meningkat. Kemampuan baca tulis dalam bahasa Arab dengan menggunakan sarana belajar mandiri, telah banyak ditelaah orang. Asumsi yang didasarkan pada penelitian ini adalah pembelajar orang Indonesia sering mengalami kesulitan membaca dalam bahasa Arab, oleh karena itu saranan belajar mandiri sangat membantu dalam meningkatkan kemampuan menulis bahasa Arab.

SAC diperkenalkan dengan mencobakan "pathways"7 dalam memotivasi pelajar menggunakan SAC di Indonesia. Mereka mencobakan empat Pathway yang diintegrasikan dengan pendidikan agama. Pada akhir penelitian mereka menyimpulkan bahwa pathways dapat memenuhi keinginan pelajar yang tinggkat kemampuan membaca berbeda-beda. Bagi pelajar dengan kemampuan rendah pathways merupakan sebuah peta, bagi pelajar yang mampu, pathways menjadi penyegar dalam belajar pendidikan agama Islam. Selanjutnya ia menjelaskan juga bahwa pengaruh penerapan SAC diitegrasikan dalam proses belajar mengajar. Penelitian berlangsung selama satu semester dan dilanjutkan dengan wawancara terhadap siswa yang diajar menggunakan SAC selama satu tahun program penelitian selesai. Hasil wawancara menunjukkan bahwa dengan belajar SAC siswa dapat meningkatkan kemampuan belajar agama Islam khusus dalam baca tulis Alquran. Siswa juga mengaatakan bahwa materi pelajaran agama Islam menggunakan SAC relative lebih menarik dibandingkan

\footnotetext{
7 Zamronie. Refleksi Pelaksanaan Kurikulum Berbasis Kompetensi pada Tingkat Sekolah Menengah. Yogyakarta: 2004), h. 35.
} 
materi pelajaran yang digunakan di dalam kelas pada umumnya, dan belajar di dalam SAC relative lebih menarik dibandingkan dengan belajar di dalam kelas biasa.

Penelitian di dalam SAC juga sudah diadakan di tingkat sekolah menengah pertama di Indonesia pada pengajaran Agama Islam. ${ }^{8}$ Pelaksanaan penelitian ini di dasarkan pada dua temuan penelitian sebelumnya; pertama, yang menyatakan bahwa strategi belajar yang efektif dalam belajar agama dapat diajarkan kepada pelajar yang belum dapat membaca huruf Arab, dan pelajar perlu mengetahu bagaimana cara belajar dengan mengadakan pelatihan dan kedua ditemukan beberapa strategi belajar membacara tulis Alquran dalam ranah pendidikan agama Islam yang efektif yang dilakukan pelajar. ${ }^{9}$ Sampel penelitian adalah 126 siswa yang ikut belajar agama Silam. Pelajar itu dibagi dalam dua kelompok eksperimen dan yang satu lagi dalam kelompok kontrol. Kepada kelompok eksperimen diperkenalkan strategi belajar yang efektif setelah pretest diadakan, dengan menggunakan informed technique. Setelah strategi belajar diperkenalkan kepada kelompok eksperimen, kedua kelompok ditugaskan untuk belajar secara mandiri di dalam SAC selama 8 minggu. Pada akhir program keempat kemampuan berbahasa, mendengar, berbicara, membaca, dan menulis diukur dengan menggunakan test. Hasil penelitian menunjukkan bahwa kelompok eksperimen menunjukkan hasil yang lebih baik secara signifikan pada keempat kemampuan berbahasa.

Dengan mengacu kepada hasil beberapa penelitian seperti telah diutarakan di atas, maka jelas terlihat bahwa ada kontribusi positif dalam peningkatan kemampuan berbahasa

\footnotetext{
${ }^{8}$ Abdullah. Pendidikan Agama Sangat Penting Bagi Bangsa. (Jakarta: 2002), h. 98.

${ }^{9}$ Setiyadi, A.Bambang. Pembelajaran Bahasa. (Yogyakarta: 1999), h. 60.
} 
jika sarana belajar mandiri digunakan secara efektif sebagai komponen dalam proses pengajran. Kemampuan ini dapat dilihat dari segi kebutuhan dan minat yang dimiliki pengguna. Dengan kata lain, pada saat berada di dalam SAC pada dasarnya pengguna memilih bahan yang secara langsung berhubungan dengan kebutuhannya. Hal ini akan menyebabkan timbulnya motivasi untuk belajar, karena pengguna dapat menerapkan atau mengaplikasikan secara langsung apa yang telah dipelajari.

\section{SARANA BELAJAR MANDIRI DAN PENERAPAN KURIKULUM BERBASIS KOMPETENSI}

Salah satu yang menjadi dasar diberlakukannya Kurikulum Berbasis Kompetensi selanjutnya disingkat (KBK) adalah bahwa pada akhir setiap pelajaran, pelajar memiliki kompetensi yang dapat diukur dengan kecakapan yang dimiliki setelah proses belajar mengajar berakhir. Jika dilihat kebijakan pemerintah Republik Indonesia lewat Kementerian Pendidikan Nasional lalu diikuti oleh Kementerian Agama yang memberlakukan KBK sejak tahun 2004, maka sudah seharusnya sarana belajar mandiri dijadikan satu komponen dalam pengajaran pendidikan Agama Islam. Kompetensi dasar atau kecakapan yang dituntut akan berbahasa Arab atau kompetensi yang ditargetkan seperti yang diterapkan dalam KBK akan sulit tercapai jika jam tatap muka masih tetap diterpatahankan seperti pada kurikulum sebelumnya. Dengan kata lain, jam tatap muka sudah sebaiknya ditambah. Namun, hal ini akan menimbulkan masalah karena jam tatap muka telah diatur sesuai dengan mata pelajaran pada sekolah menengah.

Solusi alternatif yang dapat ditawarkan adalah mengintegrasikan sistem belajar belajar mandiri pada proses belajar mengajar. Jika penilaian akhir ditekankan sepenuhnya terhadap pencapain kompentensi dasar bahasa Arab atau kecepakatan berbahasa Arab, maka jam tatap 
muka yang saat ini sedang diberlakukan dalam lingkungan sekolah menengah pada mata pelajaran Agama Islam sudah sebaiknya ditambah dengan mengefektifkan penggunaan sarana belajar mandiri dua hingga tiga jam per minggu. Hal ini didasarkan pada asumsi bahwa pada dasarnya siswa yang masuk ke sekolah menengah, kemampuan baca tulis huruf Arab-nya masih cukup rendah. Jika sistem yang diterapkan pada KBK, yakni bahasa Arab I (2 sks) dan bahasa Arab II (2 sks) dengan jumlah tatap muka antara 14 hingga 16 kali per 2 sks, maka hanya ada 28 hingga 32 kali tatap muka, dengan satu jam empat puluh menit per tatap muka, selama seorang siswa duduk di bangku sekolah, dengan waktu yang sesingkat ini, ditambah lagi banyaknya jumlah siswa yang berada dalam satu kelas pada saat proses belajar mengajar berlangsung, maka akan sangat minim kecakapan yang diperoleh seorang siswa pada saat tatap muka. Hal ini akan berakibat tidak terpenuhinya kebutuhan akan pemahaman teks yang berbahasa Arab pada bidang studi yang digelutinya dan terhadap kecakapan akan bahasa Arab yang dituntut pasar kerja saat ini.

\section{ULASAN}

Untuk mendapatkan hasil yang maksimum dalam penerapan belajar secara mandiri, baik pada tingkat pendidikan dasar, menengah, maupun pada perguruan tinggi, pengenalan terhadap strategi belajar yang efektif, pengembangan materi dan kegiatan belajar, pengadaan alat bantu belajar, serta sistem evaluasi dan monitoring sebaiknya dilakukan sebelum menugaskan pelajar belajar mandiri. Lebih penting lagi bahwa pelajar sudah harus mengetahui konsep belajar mandiri, dan bahwa masing-masing pelajar sudah sebaiknya menyadari bahwa konsep saling membantu dalam belajar bahasa Arab adalah yang menjadi pokok pada sarana belajar mandiri. Pengajar sebaiknya mengetahui perubahan fungsinya dari 
seorang guru pada saat tatap muka menjadi seorang fasilitator pada saat belajar secara mandiri di dalam sarana belajar mandiri. Untuk mengaktifkan pelajar menggunakan sarana belajar mandiri, tugas untuk dikerjakan di dalam sarana belajar mandiri harus diberikan pada saat tatap muka secara terprogram.

Ada pendapat yang mengatakan bahwa belajar secara otonomi tidak cocok diterapkan untuk anak-anak, untuk mempelajari bahasa yang sulit,d alam institusi yang berorientasi pada ujian, dan orang dewasa yang tingkat pendidikannya rendah (Gremmo dan Riley, 1995). Pendapat seperti ini sudah tidak up-date lagi karena hasil-hasil penelitian menunjukkan bahwa anak-anak dapat meningkatkan kemampuan mereka dalam bahasa asing. Bahasa yang dianggap sulit juga telah dipelajari dengan menggunakan SAC di beberapa negara di Eropa yang terdapat masyarakat muslim, sebagai contoh 40 bahasa asing daiajarkan dengan mengintegrasikannya dengan SAC pada Pusat Bahasa Universitas Cambridge. Penggunaan SAC juga telah diteliti pada institut yang berorientasi pada ujian. Hasilnya menunjukkan bahwa dengan menggunakan SAC, pelajar dapat meningkatkan capaian pada ujian. Demikian juga halnya dengan pembelajaran bahasa kepada orang dewasa yang berpendidikan rendah, penggunaan SAC juga dtemukan memberikan kontribusi yang positif terhadap kemampuan berbahasa. Willing dan Race mengadakan penelitian terhadap pendatang yang berlatarbalakng pendidiikan rendah (anak-anak kapal) dalam belajar bahasa Arab dengan menggunakan SAC secara efisien memberikan kontribusi positif terhadap peningkatan kemampuan berbahasa Arab. ${ }^{10}$

${ }^{10}$ Willing K. "Teaching How to Learn". (Sydney: 1988) , h. 34. 
Untuk dapat menggunakan SAC secara aktif, untuk mendukung pendukung pencapaian kompetensi yang diharapkan dalam penerapan KBK, sebaiknya pengajar agama Islam yang belajar bahasa Arab dan pelajar terlebih dahulu diperkenalkan pada sistem belajar pada SAC. Dengan demikian, pengajar akan dapat mendesain dan mengembangkan materi SAC, serta mengetahui strategi-strategi belajar yang efektif. Untuk pelajar perlu diterapkan pendekatan learning to learn dengan mengintegrasikannya dalam proses belajar mengajar di dalam kelas atau dengan melakukan pelatihan khusus sebelum ditugaskan untuk menggunakan SAC. Pimpinan, pada tingkat sekolah dasar, menengah, dan sebaiknya menyadari bahwa system belajar apapun yang diterpkan dalam proses belajar mengajar, proses ini pasti membutuhkan media pengajaran. Oleh karena itu, sudah sebaiknya ada alokasi dana untuk pengadaan sarana belajar mandiri serta fasilitas yang mendukungnya. Jika life-long education system ingin terwujud dalam masyarakat Indonesia, dasarnya harus ditanamkan sedini mungkin dengan menumbuhkembangkan kemauan belajar mandiri yang lebih popular dengan sebutan autonomous learning. Jika kecakapan akan bahasa Arab seperti yang dituntut KBK, pelajar harus diperkenalkan dengan situasi di mana bahasa Arab dalam materi pendidikan agama Islam itu dapat digunakan. Penggunaan SAC yang efektif akan membantu penerapan bahasa sesuai konteks dan kebutuhan pengguna.

Selain penerapan SCA secara aktif factor lain yang ikut menentukan adalah motivasi dari orang tua atau guru untuk menentukan keberhasilan pendidikan agama Islam yang menerapkan SAC. Pentingnya peran orang tua atau guru dalam memberi dukungan moril. Dalam belajar mandiri ini guru bukan satu-satunya sosok yang mampu mennyampaikan isi pelajaran. Dalam belajar mandiri ketergantungan terhadap guru ditiadakan sama sekali. 
Belajar mandiri merupakan cara belajar yang mementingkan motivasi dan kesadaran untuk ilmu pengetahuan. Unsur ini sangat penting untuk menentukan keberhasilan pendidikan seseorang, sebab diri sendiri yang menjadi sentral utama. Motivasi untuk belajar mandiri adalah upaya untuk meningkatkan kualitas sumber daya manusia, motivasi belajar mandiri merupakan satu faktor yang sangat dan perlu mendapat prioritas yang besar. Hal ini disebabkan motivasi belajar mandiri merupakan "darah kehidupan” pendidikan yang berhasil. Seorang siswa dalam pelaksanaan belajar mandiri dipengaruhi oleh kondisi kemanusiaa yang umumnya dimiliki manusia. Kondisi-kondisi yang dimaksud antara lain adalah komitment dan kepuasan belajar mandiri itu.

Berkaitan dengan komitmen untunk belajar mandiri ${ }^{11}$ adalah energi yang mempunyai komitmen tinggi pada diri sendiri untuk lebih produktif. Munculnya asumsi bahwa komitmen berhubungan dengan kesadaran untuk berhasil mencapai prestasi akademik siswa dan penguasaan ilmu yang digelutinya. Komitmen belajar mandiri dapat juga berarti bahwa kesediaan seseorang untuk mengorbankan waktu, tenaga yang relative banyak dari yang telah ditetapkan untuk meningkatkan pekerjaan atau pembelajaran. ${ }^{12}$

Pokok pikiran di atas memiliki kesesuaian dengan pendapat Moris ${ }^{13}$ yang mengatakan bahwa komitmen merupakan satu struktur inisiatif atau usaha serta perhatian kepada diri sendiri dan orang lain. Kesediaan serta kepedulian yang dimaksud adalah sesuatu yang muncul dari kesadaran serta diiringi oleh ketulusan yang tinggi untuk kepentingan bersama. Pendapat di atas mengimplikasikan bahwa karakteristik komitment belajar meliputi: a)

\footnotetext{
${ }^{11}$ Mathis, George. Human Resource. (Jakarta: 2000) , h. 54.

${ }^{12}$ Setyowati. Karakteristik Individu dalam Belajar Mandiri. (Malang: KHO),h. 21.

${ }^{13}$ Moris J. "Generalizablity of An Self Organization Commitment Model." (Oxford: 2001) JStor. Vol. 2 No
} 
kepercayaan yang kuat dalam menerima dan mendukung nilai serta tujuan belajar, b) bersedia dan mau menggunakan banyak usaha dengan sungguh-sungguh untuk kepentingan pekerjaan dan (c) berhasrat kuat untuk mempertahankan keanggotaannya dalam belajar ataupun bekerja. Sehubungan dengan arti pentingnya komitmen dalam konteks belajar mandiri dapat diketahui bahwa untuk mengelola sekolah dengan siswa yang dianjurkan untuk belajar mandiri maka diperlukan pengetahuan siswa yang memiliki komitmen tinggi.

Berdasarkan uraian tersebut dapat dikatakan bahwa salah satu factor penentu keberhasailan proses belajar mengajar pendidikan agama Islam yang menganut proses balajar mandiri adalah tingkat komitmen siswa. Artinya, pengelolaan proses pembelajaran menuntut penggunaan waktu, tenaga, dan perhatian yang lebih dari orang tua atau guru untuk lebih memperhatikan siswa. Pemberian waktu, tenaga, dan perhatian yang dimaksud, diharapkan benar-benar secara tulus tanpa ada perasaa terpaksa. Uraian tersebut di atas memberikan penjelasan bahwa komitmen memiliki hubungan langsung dengan performans belajar mandiri.

Kepuasan belajar mandiri memiliki makna sebagai gambaran perasaan senang atau positif dari seseorang terhadap kerja dan lingkungan belajarnya. Belajar dari pengertian tersebut sudah tentu dapat diduga bahwa kesadaran belajar mandiri seseorang dipengaruhi oleh kepuasan sarana dan kerja yang bersangkutan. 


\section{DAFTAR PUSTAKA}

Abdullah. 2002. Pendidikan Agama Sangat Penting Untuk Bangsa. Jakarta: Rineka

Dindiknas. 2002. Laporan Pendidikan Agama Islam Kabupaten Gunung Mas. Kuala Kurun: DIndiknas.

Kementerian Agama. Pendidikan Agama Islam. (Pedoman Pendidikan Agama di Sekolah). Jakarta: Kementerian Pedndidikan Agama (Jakarta: 1999)

George, Mathis. Human Resource. Jakarta: Salemba Emban

Lindsay Miller and David Gardner. Establishing Self-Access: From Theory Practice. (Cambdrige: 1999).

Moris J. 2001 "Generalizablity of An Self Organization Commitment Model." Oxford: JStor. Vol. 2 No. 2.

Setyowati. 1997. Karakteristik Individu. Malang: KHO.

Susan Sheerin. 1989. "Self-Acces"; Resource Book for Teachers. Oxford: OUP.

Willing, K. 1981. Teaching how to learn. Sydney: Macquire

Zamroni. 2004. Refleksi Pelaksanaan Kurikulum Berbasis Kompetensi. Yogyakarta: Universitas Negeri Yogyakarta.

Setyowati. Karakteristik Individu dalam Belajar Mandiri. (Malang: KHO). 